\title{
РОЗРОБКА МОДЕЛІ КОРПОРАТИВНОГО УНІВЕРСИТЕТУ В ОРГАНІЗАЦІї
}

\section{DEVELOPMENT OF A CORPORATE UNIVERSITY MODEL IN ORGANIZATION}

\author{
Гапєєва Ольга Миколаївна \\ доктор економічних наук, професор кафедри, \\ Університет митної справи та фрінансів \\ ORCID: https://orcid.org/0000-0001-6320-2775 \\ Суліма Єлизавета Миколаївна \\ студентка, \\ Університет митної справи та фрінансів \\ ORCID: https://orcid.org/0000-0002-6961-9018 \\ Hapieieva Olha, Sulima Yelyzaveta \\ University of Customs and Finance
}

\begin{abstract}
Стаття присвячена дослідженню теоретичних питань сутності корпоративних університетів, проводився аналіз існуючих процесів на базі організації, її мета та основні фрункції. Чинники для створення моделі корпоративного університету, основні переваги та проблеми системи. Як корпоративні університети націлені на підвищення продуктивності та навичок співробітників з використанням останніх досягнень інорормаційних та телекомунікаційних технологій. Принципи роботи моделі на міжнародному рівні в процесі навчання працівників $з$ різних країн разом в одній організації. Основні фрактори, що гальмують створення і розвиток моделі. У роботі розглядається як вітчизняний, так і зарубіжний досвід створення корпоративних університетів, їх фрункції та вплив на розвиток персоналу за сучасних умов. Зроблено висновок стосовно впливу корпоративних університетів на розвиток персоналу.
\end{abstract}

Ключові слова: корпоративний університет, внутрішнє навчання, персонал, розвиток, менторство.

Статья посвящена исследованию теоретических вопросов сущности корпоративных университетов, проводился анализ существующих процессов на базе организации, ее цели и основные функции. Факторы по созданию модели корпоративного университета, основные преимущества и проблемы системы. Как корпоративные университеты направлены на повышение производительности и навыков сотрудников с использованием последних достижений инсормационных и телекоммуникационных технологий. Принципы работы модели на международном уровне в процессе обучения работников из разных стран вместе в одной организации. Основные фракторы, тормозящие создание и развитие модели. В работе рассматривается как отечественный, так и зарубежный опыт создания корпоративных университетов, их фрункции и влияние на развитие персонала в современных условиях. Сделан вывод о влиянии корпоративных университетов на развитие персонала.

Ключевые слова: корпоративный университет, внутреннее обучение, персонал, развитие, менторство.

The article is devoted to the study of theoretical issues of the essence of corporate universities, the analysis of existing processes based on the organization, their purpose, and main functions. Factors for creating a corporate university model, the main advantages, and problems of the system. As corporate universities, they aim to increase the productivity and skills of employees using the latest advances in information and telecommunications technology. The principles of the model at the international level in the process of training employees from different countries together in one organization. The work was based on the main factors that inhibit the creation and development of the corporate university model in organizations. The paper considers both domestic and foreign experience in creating corporate universities, their functions, and their impact on staff development in modern conditions. The corporate university model is also responsible for managing knowledge in both internal and external environments and is a big solution to the difficulty of unemployment and underemployment. Different methods were used in the process of writing the article. Mathematical methods play an important role in statistical data processing, modeling. Observation as a method of cognition, which allowed to obtain primary information about the corporate university in the form of a 
set of empirical statements. The survey provided factual information firsthand. The practical significance of this study is related to the implementation of the results obtained in "ProCredit Bank" in order to improve the financial condition and stable work in the organization without issues and good preparation for any changes in the banking sector. The analysis of the onboarding program showed the impact of a careful selection of personnel at the very beginning of the recruitment of specialists on their speed of adaptation on the readiness to work in a commercial bank with foreign capital. A conclusion is made regarding the influence of corporate universities on staff development. The study showed that the topic of corporate universities is fully developed in Ukraine yet.

Keywords: a corporate university, internal training, staff, development, mentorship.

Постановка проблеми. 3 кожним роком все більше компаній починають розуміти важливість не тільки підбору профресіоналів, а й їх подальше навчання. Бізнес не може розвиватися без досвідченого персоналу, оскільки це один з основних критеріїв конкурентоспроможності для компаній. В той час як одні організації витрачають велику кількість грошей на найм коучів 3 консалтингових та тренінгових компаній, розвинені компанії створюють на власній базі корпоративні університети. Дослідження нових фрорм і оптимальних видів моделі $€$ дійсно актуальною сучасною темою для організацій, які бачать майбутнє в розвитку власного персоналу і вплив якісного людського капіталу на бізнес.

Аналіз останніх досліджень публікацій. Тема корпоративних університетів хвилювало багатьох науковців, при написані роботи були використані роботи: А.С. Минзов, В.А. Спивак, В.Ш. Каганів, М.І. Магура, М.Б. Курбатова, Е.Н. Черемісіна, також тему розглядали такі відомі науковці: А. Кенеді, Ф. Клукхон, Т. Пітері, Л. Розенштіль, Р. Хошфед, Е. Шайн, До. Штольц, Ф. Штортбек, Д. Кіркпатрік, Д. Філіпс, С. ТодД, К. Камерон та інші. Основним не вирішеним питанням залишився розрахунок економії організацій на залучення викладачів з переліку працівників без окремого найму викладачів зовні, тобто менторство. Певна система вже давно працює закордоном, в Україні тільки розвивається в великих компаніях.

Виділення невирішених раніше частин загальної проблеми. Основним гальмом впровадження моделі корпоративного університету в українські організації $€$ відмова керівництва вкладати ресурси (час, гроші) в персонал. Також компанії при впроваджені звертаються до зовнішніх організацій для навчання працівників, а не створення власної «школи» під власні інтереси та рівень.

Постановка завдання. Метою даної статті $€$ визначення сутності поняття «корпоративне навчання», вивчення теоретичних основ i переваг корпоративного навчання у порівнянні зі звичними фрормами розвитку персо- налу, вивчення методики навчання персоналу на прикладі комерційного банку АТ «ПРОКРЕДИТ БАНК» та розробити пропозиції щодо вдосконалення університету на базі банку.

Виклад основного матеріалу дослідження. Вже більше і більше великих компаній в Україні беруть приклад з європейських компаній та їх системи навчання персоналу. Найняти гарного спеціаліста це тільки пів справи для HR відділу, а залишити його бажаним та допомагати розвиватися і стати частиною команди вже робота всіх відділів організації. Керівництво провідних компаній приймає рішення про створення корпоративних університетів для забезпечення конкурентоспроможності компанії завдяки висококваліфрікованим співробітникам та їх можливостями пристосуватися к ринковим змінам.

Корпоративний університет, по суті, те, що курси підвищення кваліфрікації. Тут співробітники проходять навчання, щоб прокачувати та розвивати свої хард та софтскіли. Це може бути навчання менеджменту, лідерства, ведення переговорів, вирішення конфрліктів. Надціль корпоративного університету - допомогти компанії виконати свою місію та реалізувати цілі, створюючи, примножуючи знання всередині компанії. 3 корпоративним університетом більше шансів не лише виростити, а й зберегти цінного співробітника, заощадити час та гроші на пошуку «своєї людини» [1].

До прикладних завдань корпоративних університетів, як правило, відносять такі:

- використання сучасних схем управління;

- оцінка та атестація співробітників, а також отримання зворотного зв'язку;

- асиміляція у компанії нових менеджерів та утримання цінних кадрів;

- розвиток управлінського потенціалу;

- навчання та розвиток персоналу (у тому числі оновлення знань, розвиток ділових навичок, культивування певних емоцій та відносин);

- підвищення особистої ефрективності кожного працівника та організації загалом;

- мотивація працівників;

- розробка та впровадження корпоративних стандартів; 
- збереження «культурної спадщини», зміцнення та розвиток корпоративної культури, що склалася [2].

Практика корпоративних університетів поширена в усьому світі і Україна вже на межі стати в перелік таких країн: насамперед, нові компанії та 3 іноземним капіталом вже с початку своєї роботи розробляють корпоративні університети на власних базах чи на прикладах інших. Одним з успішних проєктів $€$ Academy DTEK, яка у 2019 році стала переможцем конкурсу найкращих корпоративних академій світу - «Global CCU Awards 2019». Academy DTEK пропонує різні фрормати навчання, регулярно проводить міжнародні консреренції 3 корпоративного навчання, майстер-класи, круглі столи і зарубіжні тури з обміну досвідом в галузі енергетики, видобутку, енергозбереження i HR [3].

Корпоративні університети мають різні масштаби та носять різні назви, однак їх суть зводиться до наступного: корпоративний університет - вибудована система внутрішньофрірмового навчання, об'єднана єдиною концепцією і методологією, розроблена для всіх рівнів керівників і спеціалістів в рамках ідеології і стратегії розвитку компанії, а також задач, що стоять перед ії̈ окремними структурними підрозділами [4, с. 28].

Розглянемо можливості формування корпоративного університету на базі комерційного банку з іноземним капіталом АТ «ПроКредит банк». Банк розпочав свою діяльність в Україні в лютому 2001 року як банк, що надає кредити представникам мікро-, малогоі середнього бізнесу. Починаючи з 2004 року «ПроКредит Банк» зробив вибір в сторону універсалізації та розширив свій спектр послуг як для підприємців, так і для населення в цілому. Сьогодні в «роздрібному» арсеналі банку - прості, зрозумілі депозитні та карткові продукти, що розраховані на людей з різними рівнями доходу.

«ПроКредит Холдинг» - це материнська компанія для всієї групи, яка контролює більшу частину акцій у всіх установах «ПроКредит» по всьому світу. Головні фрункції «ПроКредит Холдингу» по відношенню до своїх дочірніх компаній: забезпечення акціонерним капіталом та фрінансування заборгованості, здійснення стратегічного управління та контролю. Холдинг бере активну участь в питаннях призначення менеджменту і підготовки персоналу, а також відіграє ключову роль в розробці і складанні навчальних планів для Академії «ПроКредит» в Фюрті, Німеччина, і регіональних академій. Він також сприяє якнайшвидшому поширенню кращих методик і підходів шляхом проведення регулярних семінарів та робочих груп для середнього та вищого менеджменту банків «ПроКредит» [5].

«ПроКредит Холдинг» за останні 20 років встановив нові стандарти не тільки в роботі 3 клієнтами, а й до підбору, навчанню і розвитку персоналу. Після успішного проходження відбору нові кадри, не важливо з якого напрямку: від IT до керівників відділів, приєднаються до програми адаптації «Onboarding Programme». Навчання є невід'ємною частиною всієї діяльності «ПроКредит Банку», отже, з першого дня банк вкладає значні кошти у особистісний та професійний розвиток нових співробітників.

ProCredit Onboarding Program - міжнародна програма адаптації з теоретичними та практичними модулями, які проводять спеціалісти 3 різних країн англійською мовою. Не зважаючи на те, що банк працює в Україні і в основному 3 українським бізнесом, «ПроКредит Банк» входить в склад «ПроКредит Холдинг» і частина роботи пов'язана з іноземними мовами. Це основна причина ретельного відбору на самому початку і перевірки знань англійської в претендента на вакантну позицію.

Коли кандидат пройшов всі попередні етапи відбору, то вже в якості стажера людина відправляється в Навчальний центр в Сербії для проходження Onboarding Program. Навчання проходить в такі етапи (рис. 1).

В результаті після адаптації, яка триває шість місяців, АТ «ПроКредит Банк» отримує спеціаліста, який повністю розбирається в основах економіки та банківської справи незалежно від напрямку отримання вищої освіти, знає принципи роботи саме цього банку, напрямки в наданні послуг, з якими клієнтами працює і т.п.

Окрім навчання закордоном (під час світової пандемії навчання перейшло в режим онлайн) банк використовує систему менторства.

Менторство (або менторинг) - вид наставництва, який має на увазі глибшу роботу 3 підопічними. Ментор, як досвідчений спеціаліст, непросто ділиться знаннями, а й надає моральну підтримку, допомагає у вирішенні складних завдань, і загалом позитивно впливає розвиток молодшого спеціаліста [6].

Ментору важливо:

- мати значний досвід у професійній сфері;

- бути лояльним до компанії, розділяти ії цінності та корпоративну культуру;

- розуміти структуру компанії, її напрями діяльності та розумітися на процесах свого відділу; 


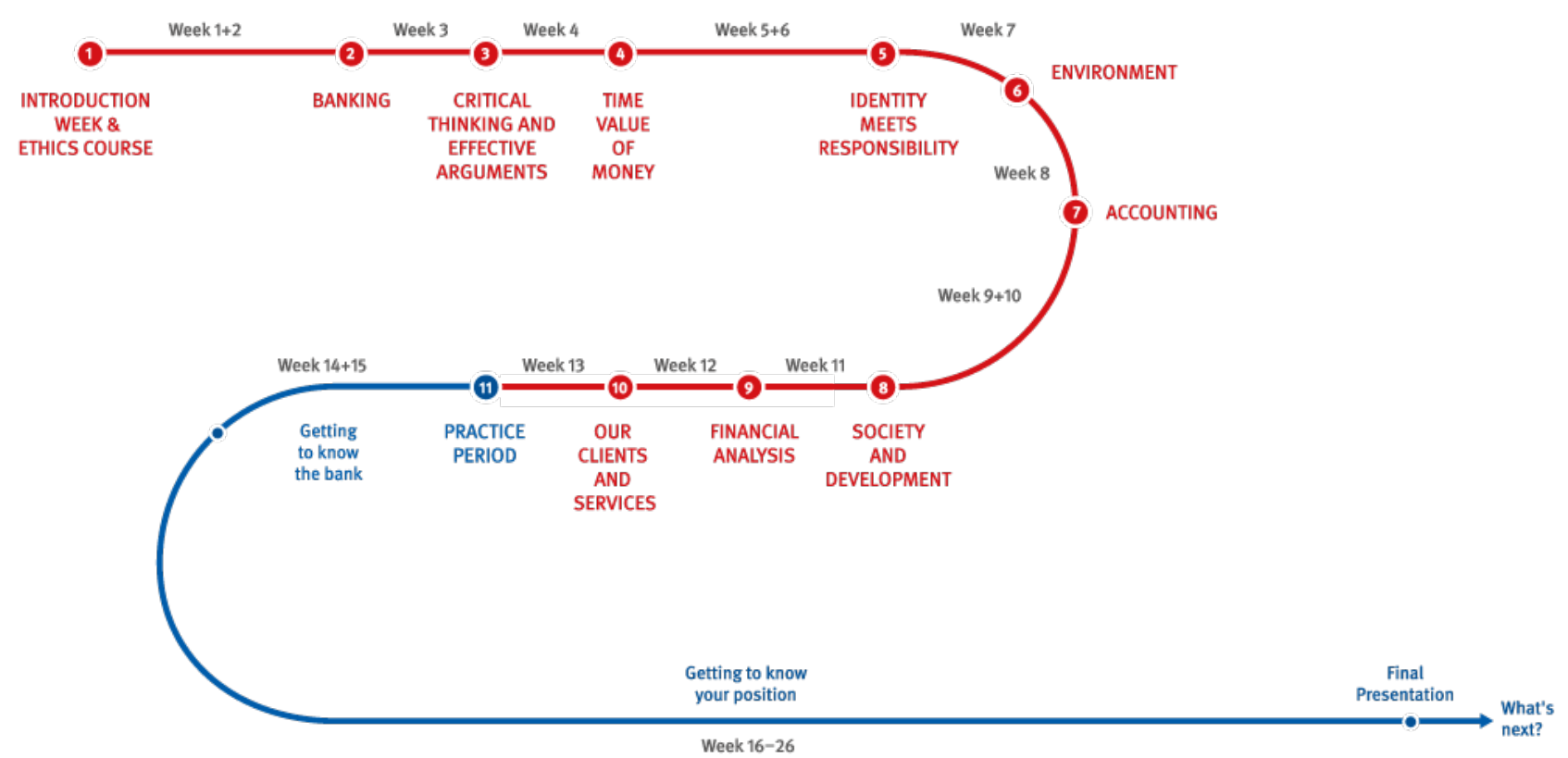

Avala Training Centre, Serbia

Рис. 1. Етапи проходження навчання в «ПроКредит Холдинг»

- бути готовим приділяти час та енергію для наставництва, оскільки це справді трудомісткий процес;

- мати бажання навчати та допомагати підопічному, а не просто контролювати та оцінювати його роботу;

- вміти висловлювати конструктивну критику і пропонувати вирішення питань;

- виявляти ініціативу і завжди бути в курсі стану справ працівника, вирішувати всі проблеми в міру їх надходження, коригуючи дії підопічного.

Менторство в Україні одна з найбільш розвинена частин корпоративного університету. В тому числі АТ «ПроКредит Банк» включає в процес навчання своїх досвідчених працівників, які допомагають в адаптації новим спеціалістам. При такому підході банк не потребує в наймі окремих наставників чи запрошувати коучів з окремих організацій на постійну основу.

Іншою важливою метою менторства $\epsilon$ позитивний вплив на загальне підвищення індивідуальних профресійних здібностей, а також на результативність фрірми. Наприклад, дослідження, що вивчають вплив програм менторства, продемонстрували збільшення утримання спеціалістів на цілих $77 \%$ і підвищення особистої продуктивності на 88\%, якщо наставництво поєднується 3 традиційним навчанням. Дослідження також показали підвищений рівень задоволеності кар'єрою та залученості до роботи серед працівників, які мали можливість брати участь у програмі менторства [7].

Вищенаведений приклад дозволяє робити висновки, що корпоративний університет AT «ПроКредит Банку» має гарний налагоджений механізм 3 постійним розвитком працівників. Це допомагає банку бути високорозвиненим і конкурентоспроможним, але $є$ деякі недоліки:

- на етапі підбору витрачається більше часу і коштів, так як не кожний український студент або спеціаліст з досвідом має достатній рівень англійської мови та підготовку до навчання по міжнародним стандартам;

- якщо у досвідчених працівників з великим навантаженням по роботі стають менторами, то не вистачає часу на навчання нових спеціалістів (обмеження часу);

- значні витрати під час Onboarding Program: переліт, житло, їжа, в разі звільнення нового спеціаліста в найближчі терміни банк втрачає даремно гроші і час вчителів.

3 метою збереження існуючої системи навчання та удосконалення її вважаємо доцільним запропонувати вдосконалити їі наступним чином:

- зменшити втрати на час під час відбору персоналу зі знаннями мов та додати в перелік документів будь-які підтвердження знань: сертифрікати, міжнародні дипломи, участь у міжнародних конфреренціях, навчання/стажування закордоном та інше; 
- перед відправою стажерів на навчання в Сербію провести стажування на місцевому рівні 3 спеціалістами з України або інших країн, де працює «ПроКредит Холдинг»;

- для менторів проводити окремі тренінги/ семінари та ретельно обирати спеціалістів за їх темпом навантаження.

Висновки. Таким чином, створення корпоративного університету напряму впливає на розвиток і прибуток організацій. Створення системи корпоративного університету доцільно при існуванні корпоративних стандартів та достатньому рівні менеджменту, який готовий до навчання та просуванню своїх працівників на високі рівні. Лише в таких умовах корпоративний університет зможе виконувати свої фрункції та сприяти розвитку спеціалістів.
Створення корпоративного університету в АТ «ПроКредит Банк» надало змогу банку вийти на високий рівень в межах країни, та на світовому рівні. Повноцінна робота HR відділу 3 спеціалістом 3 самого початку найму - його роботи, процесу адаптації та під час роботи багато років потому впливає на процес роботи як самого працівника, так і в масштабах відділення-банк-холдинг.

Отже, корпоративний університет дозволяє розв'язати низьку проблем, пов'язаних 3 персоналом і не тільки, допомагає в створені корпоративної роботи в організації та підвищує мотивацію серед працівників. Організація, в якій достатньо розвинений персонал та постійно навчається має більше шансів на успіх та постійне збільшення прибутків.

\section{СПИСОК ВИКОРИСТАНИХ ДЖЕРЕЛ:}

1. Корпоративний університет - що це та як його використовують у компаніях. URL: https://netpeak.net/ru/ blog/korporativnyy-universitet-chto-eto-i-kak-yego-ispol-zuyut-v-kompaniyakh/

2. Побудова корпоративного університету / HR-Ліга. URL: https://hrliga.com/index.php?module=profession\& op=view\&id=1195

3. Чи врятують корпоративні вузи українську освіту? URL: https://rubryka.com/article/corporate-universities/

4. Голышенкова О. Перспективы развития корпоративного образования. Менеджер по персоналу. 2008. № 4. С. 26-33.

5. Офіційний сайт «ПроКредит Банку». URL: https://www.procreditbank.com.ua/

6. Ментори в компаніях: як наставництво допомагає досягати цілей бізнесу. Режим доступу: https://hurma.work/ru/blog/mentory-v-kompaniyah-kak-nastavnichestvo-pomogaet-dostigat-czelej-biznesa/

7. Mentoring for success / Wolf management consultants. URL: https://www.wolfmotivation.com/programs/ mentoring-for-success

\section{REFERENCES:}

1. Korporatyvnyj universytet - shho ce ta yak jogo vykorystovuyut u kompaniyax [Corporate University what it is and how it is used in companies]. Retrieved from: https://netpeak.net/ru/blog/korporativnyy-universitetchto-eto-i-kak-yego-ispol-zuyut-v-kompaniyakh/

2. Pobudova korporatyvnogo universytetu / HR-Liga [Building a corporate university]. Retrieved from: https://hrliga.com/index.php?module=profession\&op=view\&id=1195

3. Chy vryatuyut korporatyvni vuzy ukrayinsku osvitu? [Will corporate universities save Ukrainian education?]. Retrieved from: https://rubryka.com/article/corporate-universities/

4. Golyshenkova O. (2008) Prospects for the development of corporate education. Personnel Manager, no. 4 , pp. 26-33.

5. Official website of ProCredit Bank. Retrieved from: https://www.procreditbank.com.ua/

6. Mentory v kompaniyax: yak nastavnycztvo dopomagaye dosyagaty cilej biznesu [Mentors in companies: how mentoring helps to achieve business goals]. Retrieved from: https://hurma.work/ru/blog/mentory-v-kompaniyah-kak-nastavnichestvo-pomogaet-dostigat-czelej-biznesa/

7. Mentoring for success / Wolf management consultants. Retrieved from: https://www.wolfmotivation.com/ programs/mentoring-for-success 